\title{
Perihilar Lymph Node
}

National Cancer Institute

\section{Source}

National Cancer Institute. Perihilar Lymph Node. NCI Thesaurus. Code C102330.

A lymph node located in the area around the hilum. 